\title{
Lipoprotein Lipase Enhances Binding of Lipoproteins to Heparan Sulfate on Cell Surfaces and Extracellular Matrix
}

\author{
Shlomo Eisenberg, " Ephraim Sehayek, * Thomas Olivecrona,' and Israel Vlodavsky* \\ Departments of ${ }^{*}$ Medicine and ${ }^{\ddagger}$ Oncology, Hadassah University Hospital, Jerusalem, Israel 91120; and ${ }^{\S}$ Department of Medical \\ Biochemistry and Biophysics, University of Umea, Umea, Sweden 90187
}

\begin{abstract}
Lipoprotein lipase enhances binding at $4^{\circ} \mathrm{C}$ of human plasma lipoproteins (chylomicrons, VLDL, intermediate density lipoprotein, LDL, and $\mathrm{HDL}_{3}$ ) to cultured fibroblasts and hepG-2 cells and to extracellular matrix. Heparinase treatment of cells and matrix reduces the lipoprotein lipase enhanced binding by 90-95\%. Lipoprotein lipase causes only a minimal effect on the binding of lipoproteins to heparan sulfate deficient mutant Chinese hamster ovary cells while it promotes binding to wild type cells that is abolished after heparinase treatment. With ${ }^{125} \mathrm{I}-\mathrm{LDL}$, lipoprotein lipase also enhances uptake and proteolytic degradation at $37^{\circ} \mathrm{C}$ by normal human skin fibroblasts but has no effect in heparinase-treated normal cells or in LDL receptor-negative fibroblasts. These observations prove that lipoprotein lipase causes, predominantly, binding of lipoproteins to heparan sulfate at cell surfaces and in extracellular matrix rather than to receptors. This interaction brings the lipoproteins into close proximity with cell surfaces and may promote metabolic events that occur at the cell surface, including facilitated transfer to cellular receptors. (J. Clin. Invest. 1992. 90:2013-2021.) Key words: lipoprotein receptors • heparinase • chylomicron remnants • Chinese hamster ovary cells • extracellular matrix
\end{abstract}

\section{Introduction}

Lipoprotein lipase is the key enzyme of the plasma fat transport system. The enzyme, situated on the luminal surface of endothelial cells, hydrolyzes triglycerides in chylomicrons and VLDL, and causes transfer of the liberated fatty acids to the tissues (1). The central role that lipoprotein lipase plays in lipoprotein metabolism is dramatically illustrated in patients with genetic defects of the enzyme and manifestations of chylomicronemia and type I hyperlipoproteinemia (2).

Another role for lipoprotein lipase in lipoprotein physiology was suggested in 1975 by Felts who proposed that the presence of the enzyme on the outer coat of lipoprotein remnant particles may direct the remnants to catabolism in the liver (3). In a recent publication, Beisiegel et al. demonstrated 20-40fold enhancement of the binding of human chylomicrons, rabbit $\beta$-VLDL, and apo E-containing liposomes to cells when lipoprotein lipase was added to the incubation mixture (4).

Address correspondence to Shlomo Eisenberg, M.D., Department of Medicine, Hadassah University Hospital, Jerusalem, Israel 91120.

Received for publication 22 January 1992 and in revised form 1 June 1992

J. Clin. Invest.

(C) The American Society for Clinical Investigation, Inc.

0021-9738/92/11/2013/09 \$2.00

Volume 90, November 1992, 2013-2021
These authors also reported increased binding of apo E liposomes to the $\alpha 2$ macroglobulin/LDL receptor-related protein (LRP) ${ }^{1}$ in the presence of lipoprotein lipase.

In the present study we investigated another possibility, namely, that lipoprotein lipase enhances, predominantly, binding of lipoproteins to an abundant cell surface molecule rather than to lipoprotein receptors. The study unequivocally demonstrated that the major effect of lipoprotein lipase is on the binding of human plasma lipoproteins to heparan sulfate on cell surfaces and in the extracellular matrix. This interaction brings lipoproteins into close proximity with cell surfaces and may promote metabolic processes that occur at the cell surface.

\section{Methods}

Preparation of lipoproteins and iodinated lipoproteins. VLDL ( $\mathrm{d}$ $<1.006 \mathrm{~g} / \mathrm{ml}$ ), IDL (d 1.006-1.019 g/ml), LDL (d 1.019-1.063 g/ $\mathrm{ml})$, and $\mathrm{HDL}_{3}(\mathrm{~d} 1.1125-1.21 \mathrm{~g} / \mathrm{ml})$ were separated sequentially from plasma obtained from normal human subjects after 12-14-h fast. The apo E phenotype of the subjects was E $3 / 3$ or E 4/3. Lipoproteins were separated by centrifugation in $60 \mathrm{Ti}$ or $50 \mathrm{Ti}$ rotors at $4^{\circ} \mathrm{C}$ in an ultracentrifuge (model L5-50; Beckman Instruments Inc., Fullerton, CA ) using standard techniques (5). The lipoproteins were washed once at a heavy density solution. VLDL density subfractions were prepared on a $\mathrm{NaCl}$ gradient in an $\mathrm{SW}-41$ rotor (Beckman Instruments) (6). All lipoproteins were dialyzed against $0.15 \% \mathrm{NaCl}, 20 \mathrm{mM}$ Tris ( $\mathrm{pH}$ $=7.4), 0.001 \%$ EDTA solution, were sterilized by passage through a $0.45-\mu \mathrm{m}$ filter (Millipore Corp., Bedford, MA) and used within 10-14 $\mathrm{d}$ of preparation. Chylomicrons were collected from the plasma of normal human subjects $4 \mathrm{~h}$ after a meal administered at a morning hour after a 12-h fast. The meal contained $\sim 1,000 \mathrm{kcal}$ with $60 \%$ of $\mathrm{kcal}$ from fat, $25 \%$ from carbohydrates, and $15 \%$ protein ( 7 ). Chylomicrons were separated by a 30-min centrifugation in an SW41 rotor at 35,000 $\mathrm{rpm}$ and $4^{\circ} \mathrm{C}$ and were washed in $0.9 \% \mathrm{NaCl}$ solution by two additional spins, $20 \mathrm{~min}$ each. The amount of chylomicron-protein was $0.5-1.0$ $\mathrm{mg}$ per $100 \mathrm{ml}$ plasma. Lipoproteins were radioiodinated with $\mathrm{Na}^{125} \mathrm{I}$ by the iodine monochloride method (8) as modified for labeling of lipoproteins (9). The final specific activity of ${ }^{125}$ I-labeled lipoproteins varied between 100 and $600 \mathrm{cpm} / \mathrm{ng}$ protein. Of the radioactivity, $1.2 \%$ ( $\mathrm{LDL}$ and $\mathrm{HDL}_{3}$ ) to $14.8 \%$ (chylomicrons) was extractable by chloroform:methanol and presumably represented ${ }^{125}$ I-labeled lipids. Rat plasma VLDL labeled biosynthetically with $\left[{ }^{3} \mathrm{H}\right]$ palmitate triglycerides was isolated by ultracentrifugation from the plasma of rats injected intravenously with $\mathrm{Na}\left[{ }^{3} \mathrm{H}\right]$ palmitate 45 min before exsanguination. Lipoprotein protein was determined according to Lowry et al. (10). Total, free, and esterified cholesterol, total phospholipids and triglycerides were determined by standard procedures (5). SDS-PAGE of apolipoproteins was performed as described by Weber and Osborn (11). The chemical composition and apolipoprotein profile of lipoproteins was similar to that described previously $(5,7,12)$.

1. Abbreviations used in this paper: bFGF, basic fibroblast growth factor; $\mathrm{CHO}$, Chinese hamster ovary; ECM, extracellular matrix; $\mathrm{HFH}$, LDL receptor-negative fibroblasts; LPDS, lipoprotein-deficient serum; LRP, LDL receptor-related protein. 
Cell cultures and extracellular matrix (ECM). Normal human skin fibroblasts, skin fibroblasts from an LDL receptor-negative homozygous familial hypercholesterolemic patient, and hepG-2 cultures were maintained as described $(5,12)$. The cells were cultured in plastic flasks (Falcon Labware, Becton, Dickinson, and Co., Oxnard, CA) in modified Dulbecco-Vogt medium and were grown with $10 \%$ FCS in a humidified incubator $\left(5 \% \mathrm{CO}_{2}\right)$ at $37^{\circ} \mathrm{C}$. Fibroblasts from the third to the fifteenth subcultures or hepG-2 cells were dissociated by trypsin treatment, plated in either 16-mm or 35-mm dishes (Falcon Labware) and grown in $2 \mathrm{ml}$ medium with $10 \%$ FCS. On the fifth day, the cells were washed with PBS and further incubated for $48 \mathrm{~h}$ in fresh medium containing $5 \mathrm{mg}$ protein $/ \mathrm{ml}$ of lipoprotein-deficient serum (LPDS). Experiments were initiated on the morning of the seventh day. The LDL receptor-negative fibroblasts and the hepG-2 cultures express the LRP receptor (Dr. U. Beisiegal, personal communication).

Wild type Chinese hamster ovary cells (CHO-K1) and mutant CHO-803 cells were kindly provided by Dr. J. D. Esko (Department of Biochemistry, University of Alabama at Birmingham). Mutant 803 produces $5-10 \%$ residual heparan sulfate and about one-half the normal level of chondroitin sulfate (13). Wild type and mutant $\mathrm{CHO}$ cells were routinely grown in Ham's F12 medium supplemented with $10 \%$ FCS and L-glutamine $(13,14)$.

Dishes coated with a naturally produced ECM were prepared as previously described (15). Cultures of bovine corneal endothelial cells were established from steer eyes (16), the cells (second to fifth passage) were plated in 16-mm or 35-mm plastic dishes and cultured in DMEM, ( 1 g glucose/liter) supplemented with $10 \%$ bovine calf serum, $5 \%$ FCS, and dextran T-40 $(15,17) .6-8 \mathrm{~d}$ after the cells reached confluence, the cell layer was treated with PBS containing $0.5 \%$ Triton X-100 and 20 $\mathrm{mM} \mathrm{NH}_{4} \mathrm{OH}$ followed by four washes with PBS. The subendothelial ECM remained intact, attached to the entire area of the dish and was free of nuclear or cellular elements (15). ECM-coated plates containing PBS were kept at $4^{\circ} \mathrm{C}$ for up to $3 \mathrm{mo}$. Metabolically sulfate $\left(\mathrm{Na}_{2}{ }^{35} \mathrm{SO}_{4}\right)$ labeled ECM was prepared as previously described (17).

Materials. Lipoprotein lipase was purified from bovine milk by established procedures (18). Recombinant basic fibroblast growth factor (bFGF) was kindly provided by Takeda Chemical Industries (Osaka, Japan) and iodinated $\left(1.2 \times 10^{5} \mathrm{cpm} / \mathrm{ng}\right)$ by Iodogen (Pierce Chemical Co., Rockford, IL) (17). Bacterial (flavobacterium heparinum) heparinase (EC 4.2.2.7, IBEX 1011) was kindly provided by Dr. J. Zimmerman (IBEX Technologies, Montreal, Canada). The enzyme is essentially free of contaminating proteolytic and glycosaminoglycan lyase activities and has a sp act of $55 \mathrm{IU} / \mathrm{ng}$. Heparin-like molecules on cell surfaces and ECM are efficiently degraded by this enzyme. Recombinant GST-39 kD protein that blocks the interaction of $\beta$ VLDL and activated $\alpha 2$ macroglobulin to the LDL receptor-related protein (LRP) (19) is a generous gift of Dr. Joachim Herz (Department of Molecular Genetics, University of Texas, Dallas). $\mathrm{Na}^{125} \mathrm{I}$ and $\mathrm{Na}_{2}{ }^{35} \mathrm{SO}_{4}$ were purchased from the Radiochemical Centre, Amersham, UK. Culture media, FCS, and antibiotics were from Gibco Laboratories, Grand Island, NY. All chemicals and reagents were of analytical grade.

Inactivation of lipoprotein lipase. Catalytically inactive unlabeled and ${ }^{125} \mathrm{I}$-labeled lipoprotein lipase were prepared by a modification of a previously published procedure (20). An enzyme solution (0.35-0.5 $\mathrm{mg} / \mathrm{ml}$ ) was mixed with concentrated quanidine solution to a final molarity of $1 \mathrm{M}$. Inactivation of the lipoprotein lipase was achieved after 16 -h incubation at $4-6^{\circ} \mathrm{C}$. Aliquots of the guanidine-lipase solutions of $1-4 \mu \mathrm{l}$ were added to $1 \mathrm{ml}$ medium and the mixture was used in the experiments. Equivalent volumes of guanidine added directly to fresh incubation media had no effects on lipoprotein binding parameters. A control-incubated lipoprotein lipase treated exactly with the same procedure but without added guanidine was used in parallel. The amount of lipase activity of the guanidine treated and of the control samples was assessed against rat plasma VLDL labeled biosynthetically with $\left[{ }^{3} \mathrm{H}\right]$ palmitate triglycerides at $37^{\circ} \mathrm{C}$ for 15 or $60 \mathrm{~min}$.

Experimental procedures. Binding of ${ }^{125} \mathrm{I}$-lipoproteins to cells and $\mathrm{ECM}$ was determined at $0^{\circ} \mathrm{C}$. On the morning of the experiment, cells and ECM were chilled on ice (60 min) and the LPDS-medium was removed and replaced after one wash with PBS by a new ice-cold minimal essential medium containing $5 \mathrm{mg} \mathrm{BSA} / \mathrm{ml}$ and $20 \mathrm{mM}$ Hepes ( $\mathrm{pH}=7.4$ ). ${ }^{125} \mathrm{I}$-lipoproteins (usually $5 \mu \mathrm{g} / \mathrm{ml}$ ) and lipoprotein lipase were added to the medium immediately before initiation of the binding experiment. Binding was allowed to take place during 60 min incubation on ice. Thereafter, the medium was removed, the cells were washed three times in PBS- $0.2 \%$ BSA and once in PBS. Bound lipoproteins were released at $0^{\circ} \mathrm{C}$ by adding $0.9 \% \mathrm{NaCl}, 10 \mathrm{mM}$ Hepes $(\mathrm{pH}$ =7) containing $5 \mathrm{mg} / \mathrm{ml}$ of sodium heparin for $1 \mathrm{~h}$, according to Goldstein et al. (21). The cells and ECM were dissolved in $0.5 \mathrm{~N} \mathrm{NaOH}$ and examined for radioactivity and protein content. In some experiments, labeled lipids in the cells were extracted with chloroform:methanol (1:1 vol/vol) (5). Culture dishes without cells and cultures incubated in the presence of 40-fold excess of unlabeled lipoproteins were processed in parallel and the values found were subtracted from the experimental values. Binding, cell association, and degradation of ${ }^{125} \mathrm{I}$ LDL in the absence and presence of lipoprotein lipase were determined as previously described $(5,12)$. The incubation mixture was similar to that described above except that LPDS medium was used. At the end of 4-h incubation at $37^{\circ} \mathrm{C}$, the medium was removed and examined for noniodide ${ }^{125} \mathrm{I}$-protein degradation products $(21)$. The cells were chilled on ice and washed extensively with ice-cold PBS- $0.2 \%$ BSA. Bound ${ }^{125} \mathrm{I}-\mathrm{LDL}$ in the washed cells was determined by release of radioactivity with sodium-heparin as above, and cell-associated radioactivity was defined as counts remaining in the cells. Binding of ${ }^{125}$ I-labeled lipoprotein lipase to cells at $0^{\circ} \mathrm{C}$ was determined by the procedure described above for lipoproteins. To determine low affinity, presumably heparan sulfate binding of ${ }^{125} \mathrm{I}-\mathrm{bFGF}$, confluent cell cultures were incubated $\left(2 \mathrm{~h}, 4^{\circ} \mathrm{C}\right)$ in DMEM containing $1 \mathrm{mg} / \mathrm{ml} \mathrm{BSA}, 20 \mathrm{mM}$ Hepes, and $2.5 \mathrm{ng} / \mathrm{ml}^{125} \mathrm{I}-\mathrm{bFGF}\left(1.2 \times 10^{5} \mathrm{cpm} / \mathrm{ng}\right)$. The cells were washed twice with binding medium and incubated $\left(5 \mathrm{~min}, 4^{\circ} \mathrm{C}\right)$ with a solution containing $1.6 \mathrm{M} \mathrm{NaCl}$ and $20 \mathrm{mM}$ Hepes, pH 7.4 and the incubation medium was assessed for radioactivity (14).

\section{Results}

Lipoprotein lipase at a protein concentration of $0.5-1 \mu \mathrm{g} / \mathrm{ml}$ markedly promoted (up to $\sim 100$-fold) binding of all human plasma lipoproteins tested (chylomicrons, VLDL-I, VLDL-III, intermediate density lipoprotein, $\mathrm{LDL}$, and $\left.\mathrm{HDL}_{3}\right)(5 \mu \mathrm{g} / \mathrm{ml})$ to normal human skin fibroblasts, LDL receptor-negative fibroblasts and hepG-2 cultures, except for binding of HDL to hepG-2 cells (Table I). Lipoprotein lipase also promoted the binding of all these lipoproteins to ECM ( Table I). The binding of chylomicrons, VLDL, and intermediate density lipoprotein, to ECM was enhanced by lipoprotein lipase to a similar extent as that observed with cells, but was considerably less for LDL and $\mathrm{HDL}_{3}$.

Treatment $\left(12 \mathrm{~h}, 37^{\circ} \mathrm{C}\right)$ of cells and ECM with heparinase $(0.05 \mathrm{U} / \mathrm{ml})$ reduced the lipoprotein lipase mediated binding of chylomicrons, VLDL, and LDL to 5-15\% the values found in untreated cells and ECM (Table II). Heparinase treatment almost completely abolished low affinity binding of bFGF to cells and ECM, a process that exclusively depends on the presence of heparan sulfate $(14,22,23)$. Use of metabolically sulfate $\left(\mathrm{Na}_{2}{ }^{35} \mathrm{SO}_{4}\right)$ labeled ECM revealed that $\sim 90 \%$ of the total incorporated radioactivity was released by treatment with the heparinase enzyme.

In another experiment, cells were first allowed to interact at $0^{\circ} \mathrm{C}$ with lipoprotein lipase (15-500 $\mathrm{ng}$ protein $\left./ \mathrm{ml}\right)$. Unbound lipoprotein lipase was removed and new medium containing ${ }^{125} \mathrm{I}$-lipoproteins ( $5 \mu \mathrm{g}$ protein $/ \mathrm{ml}$ ) without lipoprotein lipase was added. Binding of the lipoproteins to the cells was determined after an additional 1 -h incubation at $0^{\circ} \mathrm{C}$. Data for VLDL-II and LDL in normal skin fibroblasts are shown in Fig. 
Table I. Effect of Lipoprotein Lipase on the Binding of Human Plasma Lipoproteins to Cultured Cells and to Extracellular Matrix

\begin{tabular}{|c|c|c|c|c|c|c|c|c|}
\hline & \multicolumn{2}{|c|}{ NSF } & \multicolumn{2}{|c|}{ HFH } & \multicolumn{2}{|c|}{ HepG-2 } & \multicolumn{2}{|c|}{ ECM } \\
\hline & $-\mathrm{LPL}$ & $+\mathrm{LPL}$ & $-\mathbf{L P L}$ & +LPL & - LPL & $+\mathrm{LPL}$ & $-L P L$ & $+\mathrm{LPL}$ \\
\hline Chylomicrons & 3.7 & 580.6 & 1.8 & 316.8 & 1.7 & 63.6 & 5.1 & 493.0 \\
\hline VLDL-I & 5.4 & 519.4 & 5.2 & 223.1 & 5.5 & 45.3 & - & - \\
\hline VLDL-III & 8.0 & 980.0 & 1.8 & 481.0 & 1.3 & 90.9 & 3.5 & 348.2 \\
\hline IDL & 26.5 & 505.0 & 5.1 & 196.8 & 10.1 & 39.6 & 19.5 & 241.0 \\
\hline LDL & 14.0 & 906.0 & 0.9 & 373.5 & 2.8 & 60.6 & 4.6 & 89.5 \\
\hline HDL-3 & 2.4 & 39.2 & 0.4 & 12.1 & 1.9 & 1.6 & 2.4 & 6.0 \\
\hline
\end{tabular}

Data are expressed in nanograms lipoprotein protein per milligram cell or ECM protein. Binding of lipoproteins was determined after 60 min incubation at $0^{\circ}$ as described in Methods. The concentration of lipoproteins used was $5 \mu \mathrm{g}$ protein $/ \mathrm{ml}$. The studies with chylomicrons, VLDL-III, and LDL were carried out in 35- $\mathrm{mm}$ plastic dishes and $1 \mu \mathrm{g} / \mathrm{ml}$ of bovine milk lipoprotein lipase. The studies with VLDL-I, intermediate density lipoprotein, and HDL-3 were carried out in 16- $\mathrm{mm}$ plastic dishes and $0.5 \mu \mathrm{g} / \mathrm{ml}$ of bovine milk lipoprotein lipase. Data are mean of triplicate dishes. The range of values between the different dishes was $<10-20 \%$ in all experiments.

1. Lipoprotein lipase bound to the cells had almost the same capacity to bind lipoprotein as lipoprotein lipase present in the incubation medium together with the lipoproteins. Similar results were obtained with $\mathrm{LDL}$ receptor-negative fibroblasts (data not shown). It thus appears that the lipoprotein lipase molecules bound to heparan sulfate at the cell surface are responsible for the binding of the lipoproteins. This conclusion is supported by the observation that pretreatment of the cells with heparinase abolished the enhanced binding of lipoproteins, similar to the effect shown in Table II.

In the experiments shown in Tables I and II, cell-associated

Table II. Effect of Heparinase Treatment on the Enhanced Lipoprotein Lipase-mediated Binding of Lipoproteins to Cells and Extracellular Matrix

\begin{tabular}{|c|c|c|c|c|c|}
\hline \multirow[b]{2}{*}{ Lipoprotein } & \multirow[b]{2}{*}{ Cell } & \multicolumn{2}{|c|}{-Heparinase } & \multicolumn{2}{|c|}{ +Heparinase } \\
\hline & & $-\mathbf{L P L}$ & $+\mathrm{LPL}$ & $-\mathbf{L P L}$ & $+\mathrm{LPL}$ \\
\hline \multirow[t]{3}{*}{ Chylomicrons } & NSF & 9.6 & 987.8 & 13.8 & 85.2 \\
\hline & HFH & 5.1 & 720.6 & - & 70.6 \\
\hline & ECM & 12.0 & 507.0 & 16.5 & 64.5 \\
\hline \multirow[t]{3}{*}{ VLDL-I } & NSF & 8.4 & 519.4 & - & 36.8 \\
\hline & HFH & 6.5 & 223.1 & - & 19.5 \\
\hline & ECM & 5.5 & 79.4 & - & 23.1 \\
\hline VLDL-III & HFH & 4.0 & 171.3 & 4.0 & 30.1 \\
\hline \multirow[t]{3}{*}{ LDL } & NSF & 39.6 & 498.0 & 44.8 & 80.1 \\
\hline & $\mathrm{HFH}$ & 3.5 & 146.9 & 1.9 & 8.3 \\
\hline & $\mathrm{ECM}$ & 4.0 & 46.0 & 3.0 & 14.0 \\
\hline \multirow[t]{3}{*}{ bFGF } & NSF & 13,000 & - & 400 & - \\
\hline & HFH & 17,200 & - & 100 & - \\
\hline & ECM & 21,900 & - & 2450 & - \\
\hline
\end{tabular}

Data are expressed in nanograms lipoprotein-protein per milligram cell protein (lipoproteins) or counts per minute per well (bFGF). Binding of lipoproteins to cells without or after heparinase treatment $\left(12 \mathrm{~h}, 37^{\circ} \mathrm{C}, 0.05 \mathrm{U} / \mathrm{ml}\right.$ followed by one wash with PBS) was determined after $60 \mathrm{~min}$ incubation at $0^{\circ} \mathrm{C}$ as described in Methods. The concentration of lipoproteins was $5 \mu \mathrm{g}$ protein $/ \mathrm{ml}$, and of lipoprotein lipase, $0.5 \mu \mathrm{g}$ protein $/ \mathrm{ml}$. Data are mean of triplicate dishes. The range of values between different determinations was $<15 \%$ in all experiments. radioactivity was detected after incubations with or without lipoprotein lipase. The amount of cell-associated radioactivity was $8-35 \%$ or $3-13 \%$ that of the heparin releasable radioactivity after binding of chylomicrons and VLDL or LDL, respectively. About $60 \%$ of the cell associated radioactivity after incubation with chylomicrons or VLDL and $20 \%$ after incubation with LDL was extractable with chloroform:methanol and presumably represented ${ }^{125} \mathrm{I}$-labeled lipids.

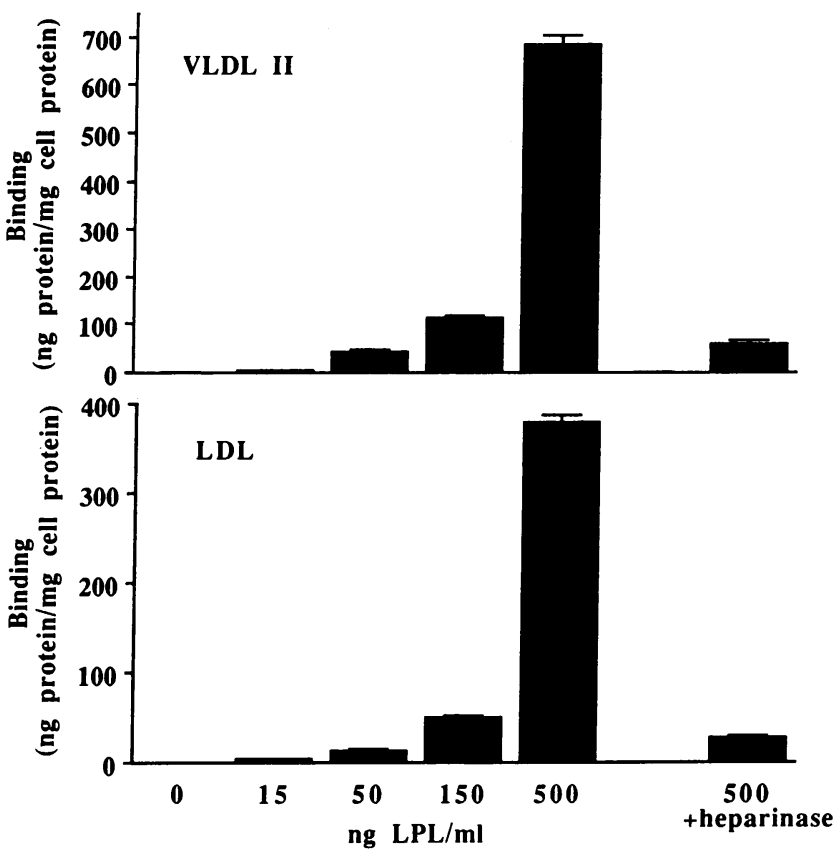

Figure 1. Binding of ${ }^{125} \mathrm{I}-\mathrm{VLDL}-\mathrm{II}$ and ${ }^{125} \mathrm{I}-\mathrm{LDL}$ to normal skin fibroblasts preincubated with lipoprotein lipase. Cells were preincubated for $60 \mathrm{~min}$ at $0^{\circ} \mathrm{C}$ with different concentrations of lipoprotein lipase: $0,15,50,150$, and $500 \mathrm{ng}$ protein $/ \mathrm{ml}$. The lipoprotein lipase-containing medium was then removed, the cells were washed once with ice-cold PBS and incubated for an additional $60 \mathrm{~min}$ at $0^{\circ} \mathrm{C}$ with fresh medium containing ${ }^{125} \mathrm{I}$-VLDL-II or ${ }^{125} \mathrm{I}-\mathrm{LDL}(5 \mu \mathrm{g}$ protein $/ \mathrm{ml}$ ). Binding of the labeled lipoproteins to the cells was determined as described in Methods. Results are mean \pm SD of triplicate dishes. Data for cells treated with heparinase and preincubated with lipoprotein lipase ( $500 \mathrm{ng}$ protein $/ \mathrm{ml}$ ) are also shown. 
Table III. Effect of Different Concentrations of Lipoprotein Lipase on the Binding of Lipoproteins to Normal and LDL Receptor-negative Human Skin Fibroblasts

\begin{tabular}{|c|c|c|c|c|c|c|}
\hline \multirow[b]{3}{*}{ Lipoprotein lipase } & \multirow[b]{3}{*}{ Heparinase } & \multicolumn{5}{|c|}{ Binding } \\
\hline & & \multicolumn{2}{|c|}{ Chylomicrons } & \multirow{2}{*}{$\frac{\text { VLDL-I }}{\text { NSF }}$} & \multicolumn{2}{|c|}{ VLDL-III } \\
\hline & & NSF & HFH & & NSF & HFH \\
\hline$n g / m l$ & & \multicolumn{5}{|c|}{ ng lipoprotein protein/mg cell protein } \\
\hline 0 & - & 9.6 & 5.1 & 18.2 & 12.1 & 4.0 \\
\hline 10 & & 17.2 & 6.9 & - & 16.8 & - \\
\hline 50 & - & 132.2 & 144.5 & 74.2 & 35.3 & 15.3 \\
\hline 150 & - & 846.6 & 498.8 & - & 131.1 & 53.6 \\
\hline 500 & - & 987.8 & 720.6 & 519.4 & 542.8 & 171.3 \\
\hline 50 & + & 13.9 & 4.3 & 15.7 & - & - \\
\hline
\end{tabular}

Binding of lipoproteins to the cells was determined at $0^{\circ} \mathrm{C}$ under conditions identical to those described in the legend to Tables I and II. Lipoproteins were used at a protein concentration of $5 \mu \mathrm{g} / \mathrm{ml}$ and were supplemented with unlabeled lipoprotein lipase at the protein concentrations shown in the table. Data are means of triplicated dishes. The variation between different determinations did not exceed $\pm 15 \%$ of the mean.

In an attempt to determine the minimal amount of lipoprotein lipase that is necessary for stimulation of lipoprotein binding to cells, an enzyme dose response curve was determined in normal skin fibroblasts and LDL receptor-negative fibroblasts. An effect was observed already at a lipoprotein lipase concentration of $10 \mathrm{ng}$ protein $/ \mathrm{ml}$ and a considerably enhanced binding was obtained at a concentration of $50 \mathrm{ng} / \mathrm{ml}$ (Table III). Pretreatment of the cells with heparinase completely abolished the effect of $50 \mathrm{ng} / \mathrm{ml}$ lipoprotein lipase and the binding values were similar to those observed without lipoprotein lipase ( Table III).

The availability of heparan sulfate deficient mutant $\mathrm{CHO}$ cells $(13,14)$ provides a unique model to study the binding of various ligands to this molecule. Data for binding of chylomi- crons, VLDL, LDL, and HDL-3 to wild type and mutant $\mathrm{CHO}$ cells are shown in Table IV. In the wild type cells, lipoprotein lipase dramatically increased the binding of the lipoproteins to the cells and this effect was reduced to $<10 \%$ after heparinase treatment. In the heparan sulfate deficient mutant cells, lipoprotein lipase had only a minimal effect. A similar phenomenon was observed with ${ }^{125} \mathrm{I}-\mathrm{bFGF}$ ( Table IV). Binding of ${ }^{125} \mathrm{I}-$ labeled lipoprotein lipase to wild type and mutant $\mathrm{CHO}$ cells was determined at two protein concentrations, $0.1 \mu \mathrm{g} / \mathrm{ml}$ and $0.4 \mu \mathrm{g} / \mathrm{ml}$. Appreciable, nonsaturable binding of lipoprotein lipase was apparent for the wild type cells that was reduced by at least $70 \%$ after heparinase treatment. Binding to the heparan sulfate deficient cells was minimal.

To ascertain that the heparinase treatment has not inter-

Table IV. Effect of Lipoprotein Lipase on the Binding of Human Plasma Lipoproteins to Wild Type and Mutant Heparan Sulfate-deficient CHO Cells

\begin{tabular}{|c|c|c|c|c|c|c|}
\hline \multirow[b]{3}{*}{ Lipoproteins } & \multicolumn{4}{|c|}{ Wild type CHO cells } & \multicolumn{2}{|c|}{ Mutant $\mathrm{CHO}$ cells* } \\
\hline & \multicolumn{2}{|c|}{-Heparinase } & \multicolumn{2}{|c|}{ +Heparinase } & \multirow[b]{2}{*}{$-\mathrm{LPL}$} & \multirow[b]{2}{*}{$+\mathrm{LPL}$} \\
\hline & $-\mathbf{L P L}$ & $+\mathrm{LPL}$ & $-\mathbf{L P L}$ & + LPL & & \\
\hline Chylomicrons & 7.7 & 341.1 & 8.0 & 32.9 & 7.9 & 13.0 \\
\hline VLDL-I & 5.9 & 170.0 & - & - & 2.0 & 4.2 \\
\hline VLDL-III & 2.7 & 108.8 & 2.9 & 9.6 & 2.4 & 5.8 \\
\hline LDL & 0.2 & 74.9 & 1.0 & 4.6 & 1.1 & 1.7 \\
\hline HDL-3 & 0.4 & 8.0 & - & - & 0.2 & 0.8 \\
\hline FGF & 10,362 & - & 1,110 & - & 1,127 & - \\
\hline \multicolumn{7}{|l|}{ LPL* $^{*}$} \\
\hline $0.1 \mu \mathrm{g} / \mathrm{ml}$ & - & $4.5 \%$ & - & - & - & $1.6 \%$ \\
\hline $0.4 \mu \mathrm{g} / \mathrm{ml}$ & - & $4.5 \%$ & - & $1.5 \%$ & - & $1.5 \%$ \\
\hline
\end{tabular}

Data are expressed in nanograms lipoprotein protein per milligram cell protein (lipoproteins) or counts per minute per well (bFGF). Binding of ${ }^{125} \mathrm{I}$-lipoproteins, ${ }^{125} \mathrm{I}$-lipoprotein lipase and ${ }^{125} \mathrm{I}$-bFGF to the cells was determined after $1 \mathrm{~h}$ incubation at $0^{\circ} \mathrm{C}$ as described in Methods. Lipoproteins were used at a protein concentration of $5 \mu \mathrm{g} / \mathrm{ml}$, and supplemented as indicated with unlabeled lipoprotein lipase at a protein concentration of $0.5 \mu \mathrm{g} / \mathrm{ml}$. Data are means of triplicate dishes.

* Because nonspecific binding of ${ }^{125} \mathrm{I}$-lipoprotein lipase to empty dishes exceeded the values observed in heparinase-treated wild type $\mathrm{CHO}$ and in mutant CHO cells, nonspecific binding was not subtracted from the experimental values. The data are therefore shown as percentage of counts that were displaced by heparin at the end of the incubation. The true binding of ${ }^{125} \mathrm{I}$-lipoprotein lipase to heparinase-treated wild type $\mathrm{CHO}$ and mutant $\mathrm{CHO}$ cells should be lower than shown in the table and is perhaps minimal. 
Table V. Effect of Heparinase Treatment and of Lipoprotein Lipase on the Cellular Metabolism of ${ }^{125} I-L D L$

\begin{tabular}{cccccccc}
\hline & & \multicolumn{3}{c}{ Normal skin fibroblasts } & & \multicolumn{2}{c}{ LDL receptor-negative fibroblasts } \\
\cline { 3 - 5 } Heparinase & $\begin{array}{c}\text { Lipoprotein } \\
\text { lipase }\end{array}$ & Binding & $\begin{array}{c}\text { Cell } \\
\text { association }\end{array}$ & Degradation & Binding & $\begin{array}{c}\text { Cell } \\
\text { association }\end{array}$ \\
\hline & $n g / m l$ & & & & & \\
Degradation
\end{tabular}

Data are expressed in nanograms LDL protein per milligram cell protein. Binding, cell association, and degradation of ${ }^{125} \mathrm{I}-\mathrm{LDL}(5 \mu \mathrm{g} \mathrm{protein} / \mathrm{ml})$ were determined after $4 \mathrm{~h}$ incubation at $37^{\circ} \mathrm{C}$ with upregulated normal skin fibroblasts or LDL receptor-negative fibroblasts as described in Methods. One-half of the cells were treated with heparinase $(0.05 \mathrm{U} / \mathrm{ml})$ for $12 \mathrm{~h}$ before the incubation with ${ }^{125} \mathrm{I}-\mathrm{LDL}$. Lipoprotein lipase (500 $\mathrm{ng}$ protein $/ \mathrm{ml}$ ) was added to ${ }^{125} \mathrm{I}-\mathrm{LDL}$ containing incubation mixture concomitantly with the initiation of the metabolic study. Data are means of triplicate plates and the variation between different determinations did not exceed $15 \%$. Similar data were observed in two additional experiments and in the study shown in Fig. 3.

fered with receptor-dependent uptake of lipoproteins by the cells, and to study the possible effects of lipoprotein lipase on the uptake and degradation of lipoproteins by cells, ${ }^{125} \mathrm{I}-\mathrm{LDL}$ was used in incubations carried out at $37^{\circ} \mathrm{C}$ ( Table V). Heparinase treatment did not affect much the binding, cell association, and degradation of LDL in normal skin fibroblasts. Addition of lipoprotein lipase to the incubation medium of cells not treated with heparinase caused an increase of the binding, association, and degradation of LDL by 80,32 , and $47 \%$, respectively. These effects were abolished after heparinase treatment, indicating that lipoprotein lipase-enhanced metabolism of LDL is perhaps due to initial binding to heparan sulfate, followed by facilitated uptake by cellular receptors. In LDL receptor-negative fibroblasts, LDL metabolism remained barely detectable either with lipoprotein lipase or after heparinase treatment, except for lipoprotein lipase-enhanced binding. Thus, if lipoprotein lipase enhanced LDL metabolism in the cells through the LRP receptor (4) then the effect must have been minimal and could not be detected. It is note-worthy that the LDL receptor-negative fibroblasts had the same capacity to degrade ${ }^{125}$ I-labeled lipoprotein lipase as the normal skin fibroblasts (Fig. 2).

To clarify further the nature of the receptor on normal skin fibroblasts that is responsible for the enhanced metabolism of LDL in the presence of lipoprotein lipase, the experiment shown in Table $\mathrm{V}$ was repeated in normal skin fibroblasts whose LDL receptor was downregulated by growth in the presence of unlabeled LDL $(80 \mu \mathrm{g}$ protein $/ \mathrm{ml})$ for $48 \mathrm{~h}$. The results are shown in Fig. 3 (binding and proteolytic degradation). The data recorded with upregulated cells were qualitatively similar to those shown in Table V, i.e., lipoprotein lipase enhanced binding and degradation of ${ }^{125} \mathrm{I}-\mathrm{LDL}$ and these effects were reduced (binding) or abolished (degradation) when the cells were pretreated with heparinase. Downregulation of the LDL receptor caused a 70-80\% decrease of the binding and degradation of ${ }^{125} \mathrm{I}-\mathrm{LDL}$ in the absence of lipoprotein lipase. Incubations in the presence of lipoprotein lipase caused enhanced binding of the ${ }^{125} \mathrm{I}-\mathrm{LDL}$ to the cells that reached a value identical or even slightly larger than that observed with upregulated cells. Degradation of ${ }^{125} \mathrm{I}-\mathrm{LDL}$ in the presence of lipoprotein lipase was also higher than that observed in the absence of lipoprotein lipase but the absolute rate of degradation was $27 \%$ that observed under the same conditions in upregulated cells. Pretreatment of the downregulated cells with heparinase reduced both the enhanced binding and enhanced degradation of ${ }^{125} \mathrm{I}-\mathrm{LDL}$ caused by lipoprotein lipase. These findings indicate that while lipoprotein lipase enhanced degradation by the cells was dependent on the status of the LDL receptor activity, the lipoprotein lipase enhanced binding was not. These conclusions are compatible with the suggestion that lipoprotein lipase enhances binding to heparan sulfate and is therefore observed to the same extent in up- and downregulated cells, whereas the lipoprotein lipase-enhanced degradation occurs predominantly through the LDL receptor pathway.

In an additional experiment an attempt was made to determine whether a $39-\mathrm{kD}$ fusion protein that specifically inhibits the interactions of lipoproteins with the LRP (19) also inhibits the lipoprotein lipase enhanced binding of lipoproteins to cells. To this end, the effects of the $39-\mathrm{kD}$ fusion protein on the lipoprotein lipase-enhanced binding of chylomicrons to hepa-

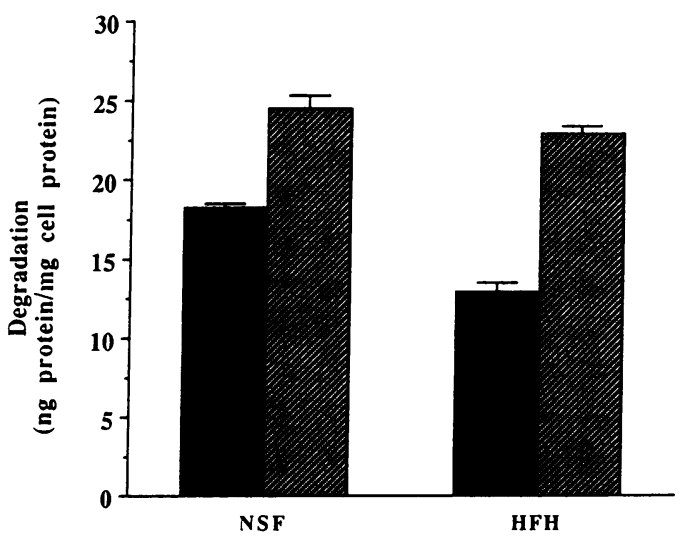

Figure 2. Degradation of ${ }^{125}$ I-labeled lipoprotein lipase by normal and LDL receptor-negative skin fibroblasts. Cultured fibroblasts were incubated at $37^{\circ} \mathrm{C}$ with ${ }^{125} \mathrm{I}$-labeled lipoprotein lipase ( $500 \mathrm{ng}$ protein $/ \mathrm{ml}$ ) for 4 and $8 \mathrm{~h}$. At the end of the incubation, the medium was collected and assayed for protein degradation products as described in Methods. In the absence of cells, no protein degradation products were identified. Data are mean \pm SD of triplicate cultures. I, $4 \mathrm{~h} ; 0,8 \mathrm{~h}$. 

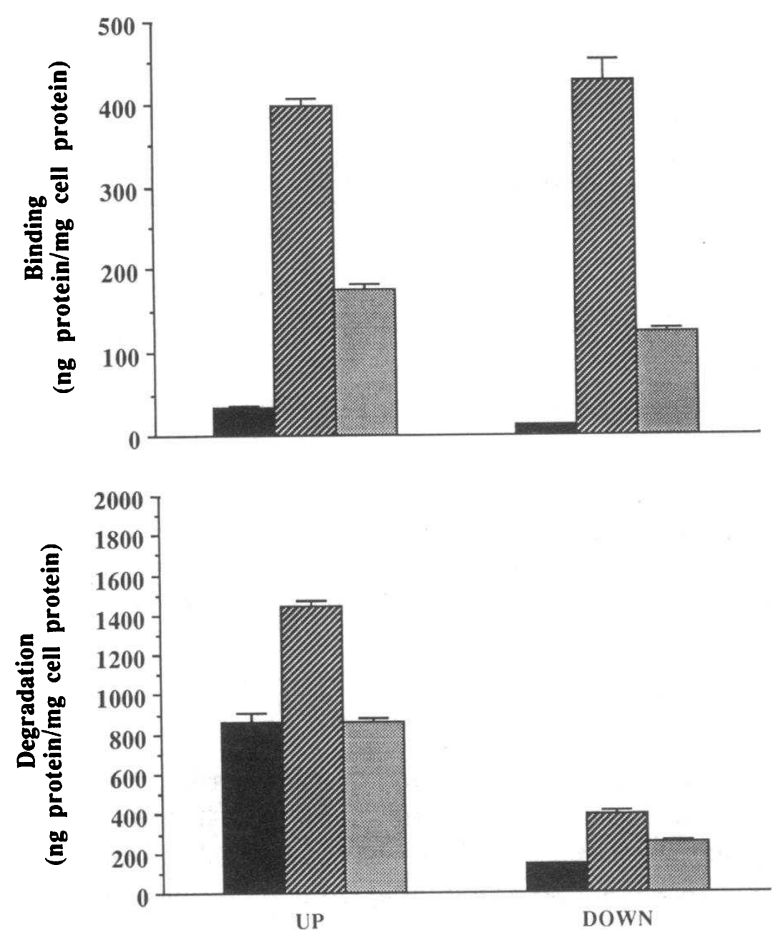

Figure 3. Effects of lipoprotein lipase and heparinase on the metabolism of ${ }^{125} \mathrm{I}-\mathrm{LDL}$ in up- and downregulated normal skin fibroblasts. Normal skin fibroblasts were up- or downregulated by growth in LPDS medium or medium containing unlabeled LDL ( $80 \mu \mathrm{g}$ protein $/ \mathrm{ml}$ ) for $48 \mathrm{~h}$ before the initiation of the experiment. ${ }^{125} \mathrm{I}-\mathrm{LDL}$ in LPDS medium was added and LDL metabolic parameters (binding, cell association, and proteolytic degradation) were determined after $4 \mathrm{~h}$ incubation at $37^{\circ} \mathrm{C}$. Effects of lipoprotein lipase and of heparinase pretreatment of the cells were determined as described in the legend to Table V. Data are for binding and proteolytic degradation and are mean $\pm \mathrm{SD}$ of triplicate cultures. $\mathrm{n},-\mathrm{LPL} ; 0,+\mathrm{LPL} ; \square,+\mathrm{LPL}$ + heparinase.

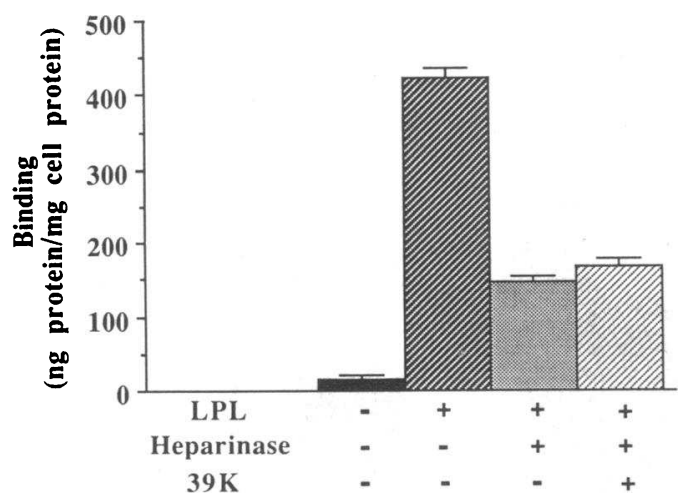

Figure 4. Effects of a 39-kD fusion protein on lipoprotein lipase enhanced binding of ${ }^{125} \mathrm{I}$-chylomicrons in heparinase pretreated LDL receptor-negative skin fibroblasts. Cells were grown as described in Methods. One-half of the cells was treated with heparinase before initiation of the binding experiment. The $39-\mathrm{kD}$ fusion protein ( 10 $\mu \mathrm{g}$ protein $/ \mathrm{ml}$ ) was added together with lipoprotein lipase (500 $\mathrm{ng}$ protein $/ \mathrm{ml}$ ) and ${ }^{125} \mathrm{I}$-chylomicrons $(5 \mu \mathrm{g}$ protein $/ \mathrm{ml})$ to heparinasetreated cultures. Lipoprotein lipase and ${ }^{125}$ I-chylomicrons were added to untreated and heparinase-treated cells at the same concentrations. Binding of ${ }^{125}$ I-chylomicrons to the cells was determined after $60 \mathrm{~min}$ incubation at $0^{\circ} \mathrm{C}$. Data are mean $\pm \mathrm{SD}$ of triplicate cultures. Similar results were obtained in normal skin fibroblasts.
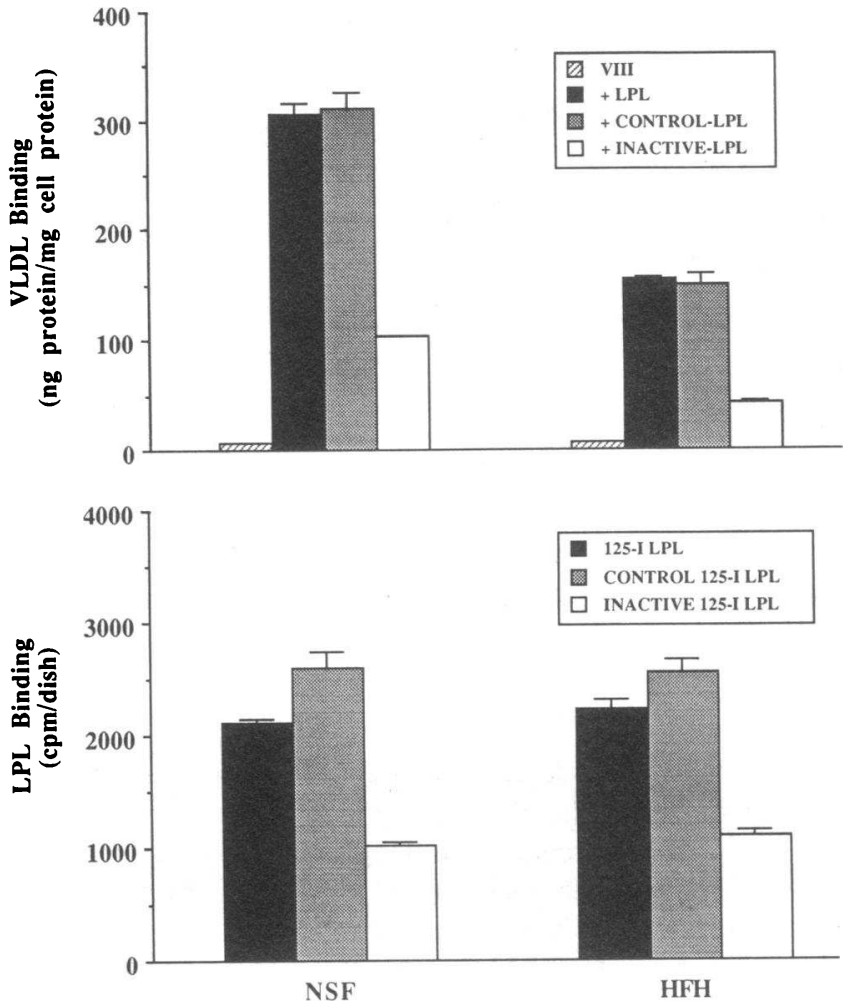

Figure 5. Effect of inactivation of lipoprotein lipase on the binding of ${ }^{125}$ I-VLDL-III and of ${ }^{125}$ I-labeled lipoprotein lipase to normal and LDL receptor-negative fibroblasts. Guanidine inactivated unlabeled and ${ }^{125}$ I-labeled lipoprotein lipase were prepared as described in Methods. Control-incubated and guanidine-inactivated lipoprotein lipase $(1,000 \mathrm{ng}$ protein $/ \mathrm{ml})$ were added together with ${ }^{125} \mathrm{I}$-VLDL-III to cell cultures, and the binding of the VLDL to the cells was determined after $60 \mathrm{~min}$ incubation at $0^{\circ} \mathrm{C}$ as described in the legend to Table I. Binding of control and inactivated ${ }^{125} \mathrm{I}$-labeled lipoprotein lipase $(31,000 \mathrm{cpm} /$ plate $)$ to the cells was determined in parallel. Data are mean $\pm \mathrm{SD}$ of triplicate cultures.

rinase-treated normal and LDL receptor-negative skin fibroblasts was determined (Fig. 4). No effect was observed. In other experiments no effects of the $39-\mathrm{kD}$ fusion protein were found in fibroblasts not treated with heparinase (data not shown). The $39-\mathrm{kD}$ fusion protein in contrast caused a $60 \%$ decrease of cholesterol esterification in the LDL receptor-negative fibroblasts after incubation with apo E-3 enriched rabbit $\beta$-VLDL using the same conditions as described by Herz et al. (19).

The lipoprotein lipase-enhanced binding of lipoproteins to heparan sulfate could be related or unrelated to the catalytic activity of the enzyme. To clarify this question, experiments were performed on normal and LDL receptor-negative fibroblasts using catalytically inactive enzyme (Fig. 5). Lipoprotein lipase was inactivated by an overnight incubation at $4-6^{\circ} \mathrm{C}$ with $1 \mathrm{M}$ guanidine as described in Methods. The inactive enzyme had no activity against rat plasma VLDL labeled biosynthetically with $\left[{ }^{3} \mathrm{H}\right]$ palmitate triacylglycerol while a control incubated (with $0.9 \% \mathrm{NaCl}$ solution) enzyme hydrolyzed $85.7 \%$ of the triglycerides. As shown in Fig. 5, totally inactive lipoprotein lipase retained $28-33 \%$ of the lipoprotein binding activity of unincubated or control-incubated enzyme. This value was $11-34$-fold higher than the binding of ${ }^{125}$ I-VLDL-III 
in the absence of lipoprotein lipase. An experiment on the binding of lipoprotein lipase itself to the cells (conducted with ${ }^{125} \mathrm{I}$ labeled enzyme treated exactly as the unlabeled enzyme) indicated that the partial inhibition of binding of VLDL to the cells by the inactive enzyme is due to reduced ability of the guanidine-treated lipoprotein lipase to bind to heparan sulfate (Fig. 5 ). It thus appears that the lipoprotein lipase-enhanced binding of lipoproteins to heparan sulfate is independent of the catalytic activity of the enzyme, at least in part.

\section{Discussion}

The structure of lipoprotein lipase, a triglyceride hydrolase that plays a key role in lipoprotein metabolism, has been elucidated in recent years (24). The enzyme molecule contains several functional regions, including a lipid-binding region and a hepa$\mathrm{rin} / \mathrm{heparan}$ sulfate-binding region (25). The heparin-binding region appears to be responsible for binding of the enzyme to heparan sulfate on cell surfaces, while the lipid-binding region appears to be responsible for interaction of the enzyme with lipoprotein particles. The results of the present study are compatible with these notions. We suggest that lipoprotein lipase forms a "bridge" between lipoproteins and heparan sulfate on cell surfaces and extracellular matrix. This action is independent of the catalytic activity of the enzyme. Our experiments show that lipoprotein lipase bound to heparan sulfate retains its capacity to bind lipoproteins. It is also possible that lipoprotein lipase binds first to lipoprotein surfaces and then the lipoprotein-enzyme complex binds to the heparan sulfate. Either mechanism may be important in physiological reaction. For example, the first is responsible for triglyceride transport in tissues that express the lipoprotein lipase gene, and the second for clearance of lipoprotein-enzyme complexes such as chylomicron and VLDL remnants.

Several investigations indicated that lipoprotein lipase enhances the interaction of lipoproteins with cells. Studies from the Steins' laboratory have demonstrated that lipoprotein lipase promotes transfer of cholesteryl esters, their ether analogues, and ether analogues of phosphatidylcholine from various rat plasma lipoproteins and from liposomes to cells in culture (26-28). The reaction presumably is mediated by enhancing the binding of the lipoproteins to cell surfaces. Lipoprotein lipase also readily binds to the subendothelial matrix (29), retains its enzymatic activity (29), and may be responsible for retention of LDL in the extracellular matrix (30). Beisiegel et al. have recently demonstrated a dramatic effect of lipoprotein lipase on the binding of human chylomicrons, rabbit $\beta$-VLDL, and apo E liposomes to a variety of cultured cells (4). They also showed, by cross-linking techniques, that the enzyme increases binding of apo E liposomes to the LRP receptor. Our data demonstrate unequivocally that as much as 9095\% of the lipoprotein lipase-enhanced binding of lipoproteins to cell surfaces is due to interaction with heparan sulfate. This conclusion is based on our observations with heparinasetreated cells and ECM and with heparan sulfate-deficient mutant $\mathrm{CHO}$ cells. We did not find evidence for lipoprotein lipase induced binding of lipoproteins to cell surface receptors, specifcally the LDL receptor and the LRP. Although we can not rule out interaction of the lipase with the LRP (4), we believe that the majority of the remaining $5-10 \%$ of bound lipoproteins in mutant $\mathrm{CHO}$ cells and heparinase-treated cells are associated with residual heparan sulfate or other sulfated glycosaminogly- cons on the surface of the cells. It is of interest to note that cell surface heparan sulfate contains regions of saccharide composition and sulfate content similar to that of heparin (31), as also indicated by the susceptibility of the cell surface and ECM heparan sulfate to degradation by bacterial heparinase. In fact, better results were obtained with the bacterial enzyme than with mammalian heparanase (endo- $\beta$-D-glucosanidase) (17), most likely because the latter enzyme exhibits a very strict interchain site specificity, yielding degradation fragments of higher molecular weight.

We show here that lipoprotein lipase enhances indiscriminately the binding of all human lipoproteins studied to heparan sulfate on cell surfaces and ECM, although it appears to be especially active for triglyceride-rich lipoproteins. This is not surprising, as lipoprotein lipase induces lipid hydrolysis in all plasma lipoproteins, including LDL and HDL, during in vitro incubations $(32,33)$. Yet, in whole plasma, the effect may be almost totally restricted to triglyceride-rich lipoproteins that possess much higher affinity to lipoprotein lipase as compared to the cholesterol ester-rich lipoproteins, LDL and HDL (34).

A crucial question that emerges from the present study is whether lipoprotein lipase-enhanced binding of lipoproteins to heparan sulfate is of physiological importance. To be of physiological metabolic relevance, lipoprotein lipase should not merely enhance the binding of lipoproteins to cell surfaces, but also promote uptake and degradation of the particles. Such effects were recently demonstrated by us in lipolyzed VLDL when the lipolysis process exposes unreactive apo $\mathrm{E}$ molecules on the VLDL and promotes uptake and degradation of the particles through the LDL receptor pathway (5). In the present investigation we were not able to demonstrate a direct effect of lipoprotein lipase on the uptake and degradation of LDL through the LDL receptor in heparinase-treated normal human skin fibroblasts or through the LRP in LDL receptor-negative fibroblasts. While an effect on triglyceride-rich lipoproteins might have been observed, it is impossible to discern in experiments carried out at $37^{\circ} \mathrm{C}$ between consequences of lipolysis of VLDL or chylomicrons $(5,7)$ and those due to the lipoprotein lipase molecule itself. Yet, lipoprotein lipase-enhanced binding of LDL to heparan sulfate caused a $50 \%$ increase of the proteolytic degradation of the lipoprotein, in normal skin fibroblasts, presumably by facilitated transfer of the LDL from the heparan sulfate to the LDL receptor. Effects of lipoprotein lipase on uptake and degradation of LDL were recently published. Aviram et al. reported enhanced metabolism of lipolyzed LDL in macrophages, smooth muscle cells, and normal skin fibroblasts, but not in LDL receptor-negative fibroblasts $(35,36)$. In that study, the lipolyzed LDL was isolated by gel filtration and most probably retained enzyme molecules on its surface. Williams et al. (37) observed a lipoprotein lipase enhanced uptake and degradation of LDL (but not monoclonal antibody C-7) in hepG-2 cells. A similar lipoprotein lipase-enhanced degradation of $\operatorname{LP}(\mathrm{a})$ was also reported in an abstract from the same group of investigators (38). The abstract states that the enhanced LP (a) degradation occurs predominantly through the LDL receptor pathway although some enhancement is also reported in LDL receptor-negative cells. In all these studies, a lipoprotein lipase-enhanced binding of the lipoprotein to heparan sulfate followed by facilitated transfer of the particles to receptors could have occurred but was not investigated. With chylomicrons and VLDL we found a 2-20-fold increase in binding to cell surface heparan sulfate 
that was abolished after heparinase treatment when using lipoprotein lipase concentrations as low as $10-50 \mathrm{ng} / \mathrm{ml}$. These concentrations are certainly close to those found in preheparin human plasma (8-25 ng/ml) (39) and are below those measured in postheparin plasma, $(\sim 200 \mathrm{ng} / \mathrm{ml})(40)$. It is thus possible that under physiological conditions even small amounts of lipoprotein lipase bound to circulating lipoproteins may promote their interaction with heparan sulfate on cell surfaces and ECM.

Several studies have indicated that interaction of biologically active molecules with heparan sulfate and heparinlike molecules is obligatory for proper expression of their activity. For example, heparin/heparan sulfate is required for bFGF high affinity binding $(14,15)$ and for bFGF-induced cell proliferation and myoblast differentiation $(23,41)$. Likewise, binding of vascular endothelial growth factor to its cell surface receptors has an absolute requirement for heparin and/or cell surface heparan sulfate (42). Not surprisingly, heparin and heparan sulfate proteoglycans are important regulators of cell growth and differentiation (43). Lipoprotein lipase mediated interactions of lipoproteins with heparan sulfate may also serve an important physiological function. As discussed above, such interaction could bring the lipoprotein into close proximity to cell surfaces and facilitate transfer of the particles to cellular receptors. It could also promote flux of lipid molecules between lipoproteins and cells and be responsible for influx of cholesteryl esters from the lipoproteins and efflux of unesterified cholesterol from the cells. A similar process could even be responsible for sequestration of chylomicron remnants in the liver (44), a phenomenon that recently was ascribed by Mahley and Hussain to interaction of the remnant particles with heparan sulfate on liver cells (45). It is more difficult to assume a physiological role for lipoprotein lipase-mediated binding of lipoproteins to ECM. Yet, a possible biological impact of a similar process on accretion of lipoproteins in extracellular spaces, for example during atherogenesis, cannot be ruled out. Indeed, Saxena et al. (30) demonstrated increased retention of LDL on extracellular matrix when lipoprotein lipase is added to matrix plated below a cultured endothelial cell layer. Again, the possible role of binding of the lipase to heparan sulfate was not investigated but probably provides the mechanism responsible for the observed phenomenon. In this context, it is interesting to note that macrophages and smooth muscle cells in atheromas express the lipoprotein lipase gene (46) and that involvement of arterial lipoprotein lipase in atherogenesis was postulated by Dr. Zilversmit (47). Evidently, the findings described in the present report warrant more extensive investigation of the role that lipoprotein lipase-mediated binding of lipoproteins to heparan sulfate plays in metabolic events that occur during lipoprotein-cell and lipoprotein-matrix interactions.

\section{Acknowledgments}

The excellent technical help of Ms. R. Avner, H. Lef kovitz, and E. Butbul is greatly appreciated. Immunoblots that verified the presence of the LRP receptor in the LDL receptor negative fibroblasts and the hepG-2 cultures were performed by Dr. U. Beisiegel, Hamburg, Germany. Recombinant GST $39-\mathrm{kD}$ protein was a generous gift of Dr. J. Herz, Dallas, Texas.

Wild type and mutant $-803 \mathrm{CHO}$ cells were kindly provided by $\mathrm{Dr}$. J. Esko, Department of Biochemistry, University of Alabama at Bir- mingham. This work was supported by a grant from the National Council for Research and Development (Israel) and G.S.F. (Munchen, Germany) Dismed Grant GR858 (S. Eisenberg), and a grant from the U. S. Public Health Service CA-30289, National Cancer Institute, Department of Health and Human Services (I. Vlodavsky).

\section{References}

1. Olivecrona, T., and G. Bengtsson-Olivecrona. 1987. Lipoprotein lipase from milk. The model enzyme in lipoprotein lipase research. In Lipoprotein Lipase. J. Borensztajn, editor. Evener Publishers, Inc. Chicago. 15-58.

2. Brunzell, J. D. 1989. Familial lipoprotein lipase deficiency and other causes of the chylomicronemia syndrome. In The Metabolic Basis of Inherited Disease C. R. Scriver, A. C. Beaudet, W. S. Sly, and D. Valle, editors. McGraw-Hill Inc. New York. 1165-1180.

3. Felts, J. M., H. Itakura, and R. T. Crane. 1975. The mechanism of assimilation of constituents of chylomicrons, very low density lipoproteins and remnants A new theory. Biochem. Biophys. Res. Commun. 66:1467-1475.

4. Beisiegel, U., W. Weber, and G. Bengtsson-Olivecrona. 1991. Lipoprotein lipase enhances the binding of chylomicrons to low density lipoprotein receptorrelated protein. Proc. Natl. Acad. Sci. USA. 88:8342-8346.

5. Sehayek, E., U. Lewin-Velvert, T. Chajek-Shaul, and S. Eisenberg. 1991. Lipolysis exposes unreactive endogenous apolipoprotein E-3 in human and rat plasma very low density lipoprotein. J. Clin. Invest. 88:553-560.

6. Lindgren, F. T., L. C. Jensen, and F. T. Hatch. 1972. The isolation and quantitative analysis of serum lipoproteins. In Blood Lipids and Lipoproteins. Quantitation, Composition and Metabolism. G. J. Nelson, editor. Wiley-Interscience, New York. 181-274.

7. Arnon, R., E. Sehayek, T. Vogel, and S. Eisenberg. 1991. Effects of exogenous apo E-3 and of cholesterol-enriched meals on the cellular metabolism of human chylomicrons and their remnants. Biochim. Biophys. Acta. 1085:336342.

8. McFarlane, A. S. 1958. Efficient tract labeling of proteins with iodine Nature (Lond.). 182:153.

9. Bilheimer, D. W., S. Eisenberg, and R. I. Levy. 1972. The metabolism of very low density lipoprotein proteins. Biochim. Biophys. Acta. 260:212-221.

10. Lowry, O. H., N. J. Rosebrough, A. L. Farr, and R. J. Randall. 1951. Protein measurement with the Folin phenol reagent. J. Biol. Chem. 193:265275.

11. Weber, K., and M. Osborn, 1969. The reliability of molecular weight determinations by dodecyl sulfate-polyacrylamide gel electrophoresis. J. Biol. Chem. 244:4406-4412.

12. Friedman, G., D. Gavish, T. Vogel, and S. Eisenberg. 1990. Cellular metabolism of human plasma intermediate-density lipoprotein (IDL). Biochim. Biophys. Acta. 1044:118-126.

13. Esko, J. D., K. S. Rostand, and J. L. Weinke. 1988. Tumor formation dependent on proteoglycan biosynthesis. Science (Wash. DC). 241:1092-1096.

14. Yayon, A., M. Klagsbrun, D. E. Esko, P. Leder, and J. D. Ornitz. 1991. Cell surface heparin-like molecules are required for binding of basic fibroblast growth factor to its high affinity receptor. Cell. 64:841-848.

15. Vlodavsky, I., J. Folkman, R. Sullivan, R. Fridman, R. Ishai-Michaeli, J. Sasse, and M. Klagsbrun. 1987. Endothelial cell-derived basic fibroblast growth factor:synthesis and deposition into subendothelial extracellular matrix. Proc. Natl. Acad. Sci. USA. 84:2292-2296.

16. Gospodarowicz, D., A. R. Mescher, and C. R. Birdwell. 1977. Stimulation of corneal endothelial cell proliferation in vitro by fibroblast and epidermal growth factors. Exp. Eye Res. 25:75-82.

17. Ishai-Michaeli, R., A. Eldor, and I. Vlodavsky. 1990. Heparanase activity expressed by platelets, neutrophils and lymphoma cells releases active fibroblast growth factor from extracellular matrix. Cell Regul. 1:883-842.

18. Bengtsson-Olivecrona, G., and T. Olivecrona. 1991. Phospholipase activity of milk lipoprotein lipase. Methods Enzymol. 197:345-356.

19. Herz, J., J. L. Goldstein, D. K. Strickland, Y. K. Ho, and M. S. Brown 1991. 39-kDa protein modulates binding of ligands to low density lipoprotein receptor-related protein $/ \alpha_{2}$-macroglobulin receptor. J. Biol. Chem. 266:2123221238 .

20. Wallinder, L., J. Peterson, T. Olivecrona, and G. Bengtsson-Olivecrona. 1984. Hepatic and extrahepatic uptake of intravenously injected lipoprotein lipase. Biochim. Biophys. Acta. 795:513-524.

21. Goldstein, J. L., S. K. Basu, and M. S. Brown. 1983. Receptor-mediated endocytosis of low-density lipoprotein in cultured cells. Methods Enzymol. 98:241-260.

22. Bashkin, P., M. Klagsbrun, S. Doctrow, C.-M. Svahn, J. Folkman, and I. Vlodavsky. 1989. Basic fibroblast growth factor binds to subendothelial extracellular matrix and is released by heparitinase and heparin-like molecules. Biochemistry. 28:1737-1743.

23. Rapraeger, A., A. Kru f ka, and B. R. Olwin. 1991. Requirement of hepa- 
ran sulfate for bFGF-mediated fibroblast growth and myoblast differentiation. Science (Wash. DC). 252:1705-1708.

24. Bensadoun, A. 1991. Lipoprotein lipase. Annu. Rev. Nutr. 11:217-237.

25. Persson, B., H. Jornvall, T. Olivecrona, and G. Bengtsson-Olivecrona. 1991. Lipoprotein lipases and vitellogenins in relation to the known three-dimensional structure of pancreatic lipase. FEBS (Fed. Eur. Biochem. Soc.) Lett. 288:33-36.

26. Chajek-Shaul, T., G. Friedman, G. Halperin, O. Stein, and Y. Stein. 1981. Role of lipoprotein lipase in the uptake of cholesteryl ester by rat lactating mammary gland in vivo. Biochim. Biophys. Acta. 666:216-222.

27. Friedman, G., T. Chajek-Shaul, O. Stein, T. Olivecrona, and Y. Stein. 1981. The role of lipoprotein lipase in the assimilation of cholesteryl linoleyl ether by cultured cells incubated with labeled chylomicrons. Biochim. Biophys. Acta. 666:156-164.

28. Stein, O., G. Halperin, E. Leitersdorf, T. Olivecrona, and Y. Stein. 1984. Lipoprotein lipase mediated uptake of non-degradable ether analogues of phosphatidylcholine and cholesteryl ester by cultured cells. Biochim. Biophys. Acta. 795:47-59.

29. Chajek-Shaul, T., G. Friedman, G. Bengtsson-Olivecrona, I. Vlodavsky, and R. Bar-Shavit. 1990. Interaction of lipoprotein lipase with subendothelial extracellular matrix. Biochim. Biophys. Acta. 1042:168-175.

30. Saxena, U., M. G. Klein, T. M. Vanni, and I. J. Goldberg. 1992. Lipoprotein lipase increases low density lipoprotein retention by subendothelial cell matrix. J. Clin. Invest. 89:373-380.

31. Nader, H. B., C. P. Dietrich, V. Buonassisi, and P. Colburn. 1987. Heparin sequences in the heparan sulfate chains of an endothelial cell proteoglycan. Proc. Natl. Acad. Sci. USA. 84:3565-3569.

32. Deckelbaum, R. J., S. Eisenberg, Y. Oschry, and T. Olivecrona. 1982. Reverse modification of human plasma low density lipoprotein toward triglyceride rich precursors. A mechanism for losing excess cholesterol ester. J. Biol. Chem. 257:6509-6517.

33. Deckelbaum, R. J., S. Eisenberg, Y. Oschry, E. Granot, I. Sharon, and G. Bengtsson-Olivecrona. 1986. Conversion of human plasma high density lipoproteins-2 to high density lipoproteins-3. Roles of neutral lipid exchange and triglyceride lipases. J. Biol. Chem. 261:5201-5208.

34. Clay, M. A., G. J. Hopkins, C. P. Ehnholm, and P. O. Bailer. 1989. The rabbit as an animal model of hepatic lipase deficiency. Biochim. Biophys. Acta. 1002:173-181
35. Aviram, M., E. L. Bierman, and A. Chait. 1988. Modification of low density lipoprotein by lipoprotein lipase or hepatic lipase induces enhanced uptake and cholesterol accumulation in cells. J. Biol. Chem. 263:15416-15422.

36. Aviram, M., S. Lund-Katz, M. C. Phillips, and A. Chait. 1988. The influence of the triglyceride content of low density lipoprotein on the interaction of apolipoprotein B-100 with cells. J. Biol. Chem. 263:16842-16848.

37. Williams, K. J., K. A. Petrie, R. W. Brocia, and T. L. Swenson. 1991 Lipoprotein lipase modulates net secretory output of apolipoprotein B in vitro. A possible pathophysiologic explanation for familial combined hyperlipidemia. $J$. Clin. Invest. 88:1300-1306.

38. Williams, K. J., G. M. Fless, K. Petrie, M. L. Snyder, R. W. Brocia, T. L. Swenson. 1991. Lipoprotein lipase enhances cellular catabolism of lipoprotein (a). Circulation. 84(Suppl. II):566.

39. Kern, P. A., R. A. Martin, J. Carty, I. J. Goldberg, and J. M. Ong. 1990 Identification of lipoprotein lipase immunoreactive protein in pre- and postheparin plasma from normal subjects and patients with type I hyperlipoproteinemia. J. Lipid Res. 31:17-26.

40. Babirak, S. P., P.-H. Iverius, W. Y. Fujimoto, and J. D. Brunzell. 1989. Detection and characterization of the heterozygote state for lipoprotein lipase deficiency. Arteriosclerosis. 9:326-334.

41. Ornitz, D. M., A. Yayon, J. G. Flanagan, C.-M. Svahn, E. Levi, and P. Leder. 1991. Heparin is required for cell-free binding of bFGF to a soluble receptor and for mitogenesis in whole cells. Mol. Cell. Biol. In press.

42. Gitag-Goren, H., S. Sokes, I. Vlodavsky, and G. Neufeld. 1992. The binding of vascular endothelial growth factor to its receptor is dependent on cell surface associated heparin-like molecules. J. Biol. Chem. 267:6093-6098.

43. Ruoslahti, E., and Y. Hamabuchi. 1991. Proteoglycans as modulators of growth factor activities. Cell. 64:867-869.

44. Stein, O., Y. Stein, D. S. Goodman, and N. H. Fidge. 1969. The metabolism of chylomicron cholesteryl ester in rat liver. J. Cell Biol. 43:410-431.

45. Mahley, R. W., and M. M. Hussain. 1991. Chylomicron and chylomicron remnant catabolism. Curr. Opin. Lipidol. 2:170-176.

46. Yla-Herttuala, S., B. A. Lipton, M. E. Rosenfeld, I. J. Goldberg, D. Steinberg, and J. L. Witztum. 1991. Macrophages and smooth muscle cells express lipoprotein lipase in human and rabbit atherosclerotic lesions. Proc. Natl. Acad. Sci. USA. 88:10143-10147.

47. Zilversmit, D. B. 1979. Atherosclerosis: a postprandial phenomenon. Circulation. 60:473-485. 